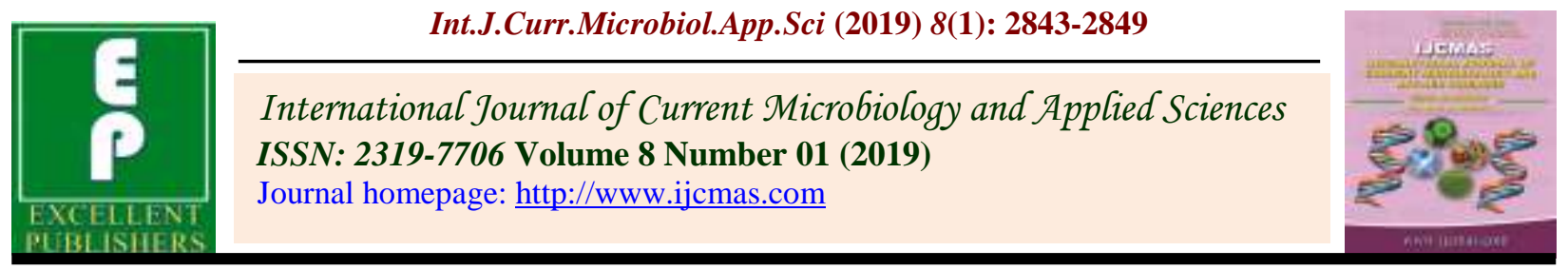

Original Research Article

https://doi.org/10.20546/ijcmas.2019.801.298

\title{
Effect of Enzyme Concentration on Quality of Apple Pomace Pectin
}

\author{
Vinay Chandel, Devina Vaidya, Anil Gupta*, Manisha Kaushal and Anil Kumar Verma
}

Department of Food Science and Technology, Dr Y S Parmar University of Horticulture and Forestry, Nauni, Solan (HP), India

*Corresponding author:

\section{A B S T R A C T}

\begin{tabular}{|c|}
\hline Keywords \\
\hline $\begin{array}{l}\text { Apple pomace, } \\
\text { Pectin, eco-friendly } \\
\text { enzymes, Jelly } \\
\text { grade, Methoxyl } \\
\text { content }\end{array}$ \\
\hline Article Info \\
\hline $\begin{array}{l}\text { Accepted: } \\
17 \text { December } 2018 \\
\text { Available Online: } \\
\text { 10 January } 2019\end{array}$ \\
\hline
\end{tabular}

\section{Introduction}

Apple pomace is obtained as a main byproduct of juice industry, consisting of 25-35 percent of dry mass of apples (Kaushal et al., 2002). It is the solid residue consisting of peel, core, seed, calyx, stem and soft tissue (Francielo et al., 2008). Apple pomace is a rich source of pectin (Bhushan et al., 2008) containing $16.95 \%$ pectin with a very high biological oxygen demand i.e. $240-19000$ mg/l (Joshi and Joshi, 1990). Several methods have been tried to extract pectin involving acids, alkalines and enzymes. Pectin's are obtained from apple pomace and citrus peels in a chemical way industrially with strong acids such as oxalic (Koubala et al., 2008), hydrochloric (Hwang et al., 1998), nitric (Constenla and Lozano, 2003) and sulphuric acids (Garna et al., 2007) which are regarded as conventional acid extraction methods (Yapo, 2009). Although these chemical procedures have advantages from an efficient and economical point of view, but they may cause environmental problems by producing hazardous contaminants that need cumbersome methods for treatment. Serious consumer concerns about chemical additives have become so dominant that the growth rate of natural products in the food industry has 
begun to rise (Sloan, 2010). Therefore, some efforts are required to minimize the use of harmful chemicals and replace with enzymes for pectin isolation.

Enzymatic extraction has been conducted with polygalacturonase (Contreras-Esquivel et al., 2006), hemicellulase and cellulase (Shkodina et al., 1998), protease (Zykwinska et al., 2008) and microbial mixed enzymes (Ptichkina et al., 2008). The enzymatic extraction has been shown to achieve higher recovery of pectin than other extraction methods (Panouille et al., 2006; Ptitchkina et al., 2008). Moreover, enzymatic extraction is regarded as an environmentally safe technique as enzymes degrade the pectin by selective depolymerisation. However, Panouille et al., (2006) found enzymatic extraction more expensive than other extraction methods, such as acid extraction. Yuliarti et al., (2011) evaluated the effect of celluclast $1.5 \mathrm{~L}$ on the physicochemical characterization of gold kiwifruit pectin and with different enzyme concentration $(0.1 \mathrm{ml} / \mathrm{kg}, 1.05 \mathrm{ml} / \mathrm{kg}$ and 2.0 $\mathrm{ml} / \mathrm{kg}$ ). Panouille et al., (2006) reported that enzymes can extract pectin with a higher yield from a smaller mass as compared to acid extractant. Thus, the present investigations were carried out to optimize ecofriendly enzyme and process for extraction of high grade pectin from apple pomace.

\section{Materials and Methods}

Fresh apple pomace procured from Himachal Pradesh Horticultural Produce Marketing and Processing Corporation Ltd (hpmc) Fruit Processing Plant, Parwanoo, Distt. Solan (H.P.) dried in the mechanical dehydrator $\left(55 \pm 2^{\circ} \mathrm{C}\right)$ to a moisture content of 9.28 percent. Fresh and dried apple pomace was analyzed for different quality characteristics. Dried apple pomace was turned into powder by passing through the Pulverizer (6000$18000 \mathrm{rpm}$ ) ultra-centrifugal mill by Bajaj process pack, Noida, UP.

\section{Optimization of enzymes for pectin extraction}

Rehydrated apple pomace powder was treated with different enzymes viz., cellulase, hemicellulase, amylase and xylanase procured from Sigma Aldrich.

The enzymatic activity of cellulase from Trichoderma viride off white powder was 0.8 -1.8U/mg, hemicullase from Aspergillus niger in powder form with 0.3-3.0 unit/mg, xylanase from Thermomyces lanuginosus with activity of 2500units/g and maltogenic amylase A2986-10G. To enhance the activity of enzyme the $\mathrm{pH}$ of rehydrated pomace was regulated at 4.5 (citrate buffer). Keeping pectin yield as an indicator, specific concentration and time of extraction of enzyme were optimized.

\section{Physico-chemical analysis of apple pomace and pectin}

Moisture, total soluble solids, titratable acidity, ascorbic acid, ash, crude protein, pectin as calcium pectate, equivalent weight, methoxyl content, anhydrogalacturonic acid content and degree of esterification was determined using methods detailed by Ranganna, (1997). Reducing and total sugars were estimated as per the method of Lane and Eynon, (1923) as described by Ranganna. Crude fibre was calculated by method given by Gould, (1978).

\section{Statistical analysis}

Data pertaining to physico-chemical parameters of dried apple pomace, pectin's extracted from the experiments like extraction methods viz., use of chemicals and enzymes and different precipitating agents were analyzed by Completely Randomized Design (Cochran and Cox, 1967). Three replications were recorded for each characteristic. 


\section{Results and Discussion}

Physico-chemical characteristics of apple pomace

The fresh as well as dried apple pomace was analyzed for different quality attributes. The results for dried pomace shows that the moisture content reduced to 9.28 from 81.35 percent with increased total soluble solids, total sugars, reducing sugars, titratable acidity, ascorbic acid and pectin contents $44.40 \mathrm{oB}$, $38.05 \%, 14.30 \%, 1.81 \%, 13.07 \mathrm{mg} / 100 \mathrm{~g}$ and $14.66 \%$ respectively as compared to fresh pomace $8.65 \mathrm{oB}, 6.25 \%, 2.17 \%, 0.27 \%$, $3.40 \mathrm{mg} / 100 \mathrm{~g}$ and $2.33 \%$ respectively (Table 1).

The values were found within the range reported by Devarajan (1997) and Kaushal (2008). Joshi and Attri (2006) also reported similar results with higher total sugar content (48.00 percent) and lower total ash content (1.82 per cent) on dry weight basis.

\section{Effect of enzyme concentration and treatment time on the pectin yield}

Different ecofriendly enzymes viz., cellulase, hemicellulase, amylase and xylanase were added at different concentrations to rehydrated apple pomace powder for different time intervals ( 1 to 5 hours) to study the effect of enzyme concentration and time interval on pectin yield from apple pomace powder at temperature of $50^{\circ} \mathrm{C}$ and $\mathrm{pH} 3.5$. The best combination of concentration and time on the basis of pectin yield was selected and the effect on quality of pectin extracted was studied.

Data in Table 2 show that in case of cellulase enzyme $2 \mathrm{~h}$ treatment time and $12 \mu \mathrm{g} / \mathrm{g}$ concentration found to give the highest pectin yield of 20.42 per cent from apple pomace powder. Further, among different concentration of hemicellulase enzyme higher yield was recorded with $12 \mu \mathrm{g} / \mathrm{g}$ concentration treatment for 3 hours observed with highest pectin yield of 19.87 percent.

The perusal of data in Table 2 shows the effect of amylase enzyme concentration and $3 \mathrm{~h}$ treatment time and $20 \mu \mathrm{g} / \mathrm{g}$ concentration of amylase enzyme was found to give the highest yield of 17.95 per cent pectin. Among the different concentration of xylanase enzyme mean higher yield was recorded with $12 \mu \mathrm{g} / \mathrm{g}$ enzyme concentration with $4 \mathrm{~h}$ enzyme treatment time results in the highest yield of pectin $(19.14 \%)$.

Table.1 Physico-chemical composition of apple pomace

\begin{tabular}{|l|l|l|}
\hline Attribute(s) & Fresh Pomace & Dried Pomace \\
\hline Moisture, \% & $81.35 \pm 4.05$ & $9.28 \pm 1.12$ \\
\hline TSS, ${ }^{\circ}$ Brix & $8.65 \pm 0.51$ & $44.40 \pm 5.74$ \\
\hline Titratable acidity, \% as malic acid & $0.27 \pm 0.05$ & $1.81 \pm 0.34$ \\
\hline Total sugars, \% & $6.25 \pm 0.79$ & $38.05 \pm 7.68$ \\
\hline Reducing sugar, \% & $2.17 \pm 0.16$ & $14.30 \pm 0.75$ \\
\hline Ascorbic acid, mg/100g & $3.40 \pm 0.65$ & $13.07 \pm 1.63$ \\
\hline Crude fibre, \% & $5.41 \pm 0.73$ & $31.31 \pm 4.83$ \\
\hline Crude protein, \% & $2.70 \pm 0.70$ & $6.12 \pm 1.89$ \\
\hline Ash content, \% & $0.85 \pm 0.14$ & $5.44 \pm 0.38$ \\
\hline Pectin, \% as calcium pectate & $2.33 \pm 0.60$ & $14.66 \pm 3.83$ \\
\hline
\end{tabular}


Table.2 Effect of enzyme concentration and time interval on pectin yield

\begin{tabular}{|c|c|c|c|c|c|c|c|}
\hline \multirow{2}{*}{$\begin{array}{l}\text { Time intervals } \\
\text { Enzyme } \\
\text { Conc. }(\mu \mathrm{g} / \mathrm{g})\end{array}$} & \multicolumn{6}{|c|}{ Pectin yield (\%) } & \multirow[t]{2}{*}{$\mathrm{CD}_{(0.05)}$} \\
\hline & $1 \mathrm{hr}$ & $2 \mathrm{hr}$ & $3 \mathbf{~ h r}$ & $4 \mathrm{hr}$ & $5 \mathrm{hr}$ & Mean & \\
\hline & \multicolumn{6}{|c|}{ Cellulase enzyme } & \\
\hline 4 & 11.58 & 14.46 & 17.26 & 18.21 & 18.02 & 15.91 & $C=0.16$ \\
\hline 12 & 15.55 & 20.42 & 18.76 & 14.96 & 13.08 & 16.55 & $\mathrm{I}=0.21$ \\
\hline 20 & 15.61 & 16.40 & 14.32 & 12.01 & 10.94 & 13.86 & $\mathrm{C} \times \mathrm{I}=0.36$ \\
\hline Mean & 14.25 & 17.09 & 16.78 & 15.06 & 14.01 & & \\
\hline \multicolumn{8}{|c|}{ Hemicellulase enzyme } \\
\hline 4 & 10.98 & 11.82 & 13.12 & 14.43 & 14.13 & 12.90 & $\mathrm{C}=0.23$ \\
\hline 12 & 13.43 & 16.36 & 19.87 & 18.18 & 16.94 & 16.96 & $\mathrm{I}=0.30$ \\
\hline 20 & 14.03 & 17.44 & 16.96 & 15.88 & 14.62 & 15.79 & $\mathrm{C} \times \mathrm{I}=0.51$ \\
\hline Mean & 12.81 & 15.21 & 16.65 & 16.16 & 15.23 & & \\
\hline \multicolumn{8}{|c|}{ Amylase enzyme } \\
\hline 4 & 10.13 & 10.50 & 11.45 & 12.25 & 11.90 & 11.25 & $\mathrm{C}=0.18$ \\
\hline 12 & 10.90 & 12.20 & 13.73 & 15.62 & 14.36 & 13.36 & $\mathrm{I}=0.24$ \\
\hline 20 & 12.73 & 15.56 & 17.95 & 16.25 & 15.70 & 15.64 & $\mathrm{C} \times \mathrm{I}=0.41$ \\
\hline Mean & 11.25 & 12.75 & 14.38 & 14.71 & 13.99 & & \\
\hline \multicolumn{8}{|c|}{ Xylanase enzyme } \\
\hline 4 & 11.22 & 13.42 & 14.98 & 16.18 & 15.12 & 14.18 & $\mathrm{C}=0.18$ \\
\hline 12 & 12.12 & 14.68 & 16.27 & 19.14 & 18.41 & 16.12 & $\mathrm{I}=0.23$ \\
\hline 20 & 12.82 & 15.34 & 17.48 & 15.43 & 11.36 & 14.49 & $\mathrm{C} \times \mathrm{I}=0.41$ \\
\hline Mean & 12.05 & 14.48 & 16.24 & 16.92 & 14.96 & & \\
\hline
\end{tabular}

Table.3 Characteristics of pectin extracted by ecofriendly enzymes with optimized concentration and treatment time

\begin{tabular}{|c|c|c|c|c|c|c|c|}
\hline $\begin{array}{l}\text { Enzyme } \\
\text { Extractants } \\
\text { Quality }\end{array}$ & $\begin{array}{l}\text { Without } \\
\text { Enzyme }\end{array}$ & Cellulase & Hemicellulase & Amylase & Xylanase & Mean & $\mathrm{CD}_{0.05}$ \\
\hline Pectin yield $(\%)$ & 17.12 & 20.42 & 19.87 & 17.95 & 19.14 & 18.90 & 0.47 \\
\hline $\operatorname{Ash}(\%)$ & 2.05 & 3.01 & 2.98 & 2.87 & 2.93 & 2.77 & 0.23 \\
\hline Equivalent weight & 1041.66 & $\begin{array}{c}1710.3 \\
2\end{array}$ & 1579.76 & $\begin{array}{c}1418.6 \\
7\end{array}$ & $\begin{array}{c}1566.2 \\
3\end{array}$ & $\begin{array}{c}1463.3 \\
3\end{array}$ & 47.06 \\
\hline $\begin{array}{l}\text { Methoxyl Content } \\
(\%)\end{array}$ & 5.15 & 5.94 & 5.61 & 5.18 & 5.53 & 5.48 & 0.21 \\
\hline $\begin{array}{l}\text { Anhydroglacturonic } \\
\text { acid (\%) }\end{array}$ & 46.13 & 44.01 & 42.98 & 41.82 & 42.63 & 43.51 & 1.01 \\
\hline $\begin{array}{l}\text { Degree of } \\
\text { esterification (\%) }\end{array}$ & 63.38 & 76.62 & 74.09 & 70.33 & 73.64 & 71.61 & 0.87 \\
\hline Jelly Grade & 70.00 & 80.00 & 76.00 & 65.00 & 74.00 & 49.00 & 9.21 \\
\hline
\end{tabular}


Table.4 Quality characteristics of enzyme extracted pectin

\begin{tabular}{|l|c|c|}
\hline $\begin{array}{l}\text { Quality Type of pectin } \\
\text { Characteristics }\end{array}$ & $\begin{array}{c}\text { Cellulase enzyme } \\
(\mathbf{1 2} \boldsymbol{\mu g} / \mathbf{g})\end{array}$ & $\begin{array}{c}\text { Commercial } \\
\text { Pectin }\end{array}$ \\
\hline Pectin yield (\%) & 20.48 & - \\
\hline Ash (\%) & 3.05 & 1.04 \\
\hline Equivalent weight & 1732.55 & 892.56 \\
\hline Methoxyl Content (\%) & 6.01 & 8.01 \\
\hline Anhydroglacturonic acid (\%) & 44.28 & 65.19 \\
\hline Degree of esterification (\%) & 77.06 & 69.75 \\
\hline Jelly Grade & 84.00 & 125 \\
\hline
\end{tabular}

\section{Optimization of enzymes for extraction of pectin}

Enzyme concentration of $12 \mu \mathrm{g} / \mathrm{g}$ was found best for cellulase (2 hours), hemicellulase (3 hours) and xylanase (4 hours) with pectin yield of 20.42, 19.87 and 19.14 percent respectively (Table 2). Whereas, in case of amylase $20 \mu \mathrm{g} / \mathrm{g}$ enzyme concentration (3 hours) was found best with 17.95 percent pectin. According to Feng et al., (2011) at high concentration and long extraction time leads to reduced pectin yield, because extending the extraction time induces degradation of pectin molecular chains under the action of enzymes, eventually affecting pectin yield.

The results presented in Table 3 shows that the yield of 17.12 percent pectin recovered without enzyme. The yield by using enzymes was low as compared to pectin extraction with citric acid $(26.88 \%)$. Similar results were reported by Lim et al., (2012), Min et al., (2010) during pectin extraction from apple pomace. Panouille et al., (2006) and Yuliarti et al., (2011) reported that enzymes can extract pectin with a high yield. On basis of pectin yield, cellulase enzyme was found better and thus optimized for pectin extraction. The quality characteristics of extracted pectin show that the highest jelly grade was obtained by using cellulase enzyme as compared to lowest jelly grade by amylase. The pectin extracted by cellulase enzyme found of better quality with equivalent weight 1710.32, anhydroglacturonic acid $44.01 \%$, methoxyl content 5.94\%, degree of esterification $76.62 \%$ and ash content of 5.94 percent (Table 3). According to Ramli and Asmawati, (2011) the increase or decrease of equivalent weight might be dependent on the free galacturonic acids. The anhydrogalacturonic acid content of pectin extracted by using enzymes was low as compared to chemically extracted pectin this might be due to the solubilization of nonpectic polysaccharides compounds during pectin extraction with enzymes, which are negatively contributing to the purity of galacturonic acid. The results were in accordance to Lim et al., (2012); Mohd et al., (2012). Min et al., (2010) reported higher degree of esterification for pectin's extracted by physical/enzymatic treatments than chemically extracted pectin.

\section{Quality characteristics of apple pomace pectin}

Table 4 shows the data of quality characteristics of enzyme extracted apple pomace pectin and compared with commercial pectin. Data show that the apple 
pomace pectin extracted by cellulase enzyme was found better as compared to the commercial pectin.

The study concludes that the apple pomace can be utilized for the extraction of pectin by using enzymatic (Cellulase @ $12 \mu \mathrm{g} / \mathrm{g}$ ) methods followed by precipitation with ethanol and drying to 8 percent moisture under dehumidifier conditions with yield of 20.48 percent pectin. Further, on the basis of quality parameters, the apple pomace pectin extracted by cellulase enzyme was found of best quality as comparable with commercial pectin. Therefore, the apple pomace can be a successful substrate and cellulase can be a better extractant for isolation and production of pectin at pilot scale.

\section{References}

Bhushan S, Kalia K, Sharma M, Singh B and Ahuja PS (2008). Processing of apple pomace for bioactive molecules. Crit Rev Biotechnol, 28:285-296.

Cochran WG and Cox CN (1967). Experimental Design. John Wiley and Sons, Inc., New Delhi.

Constenla D and Lozano JE (2003). Kinetic model of pektin demethylation. Latin Amer Appl Res, 33: 91-96.

Contreras-Esquivel JC, Voget CE, Vita CE, Perez EJD and Renard CMG (2006). Enzymatic extraction of lemon pectin by endo-polygalacturonase from Aspergillus niger. Food Sci Biotechnol, 15:163-167.

Devrajan A (1997). Solid state fermentation of apple pomace- methods of ethanol recovery, physicochemical evaluation and acceptability of animal feed produced. M.Sc. Thesis. Dr. Y S Parmar University of Horticulture and Forestry, Nauni, Solan (H.P.) India.

Feng W, Gao B, Li MY, Yin JX, and Guo CJ (2011). Study on extraction technique of pectin from watermelon peel by acid hydrolysis. $J$ Anhui Agricul Sci, 33:20577-20580.

Francielo V, Patrcia MA, Fernanda S, Elisa E and Jorge LN (2008). Apple pomace: a versatile substrate for biotechnological applications. Crit Rev Biotechnol, 28 (1): 1-12.

Garna H, Mabon N, Robert C, Cornet C, Nott $\mathrm{K}$, Legros H, Wathelet B and Paquot $\mathrm{M}$ (2007). Effect of extraction conditions on the yield and purity of apple pomace pectin precipitated but not washed by alcohol. J Food Sci, 72: C001-C009.

Gould WA (1978). Food Quality Assurance. AVI Publishing Company Inc., Westport, Connecticut.

Hwang JK, Kim CJ and Kim CT (1998). Extrusion of apple pomace facilitates pectin extraction. J Food Sci, 63: 841844.

Joshi C and Joshi VK (1990). Food processing waste management technology: Need for an integral approach. Ind Fd Packer, 44(5):56-67.

Joshi VK and Attri D (2006). Solid state fermentation of apple pomace for the production of value added products. Nat Product Rad, 5(4):289-296.

Kaushal P (2008). Studies on extraction and utilization of pectin from apple pomace. M.Sc. Thesis. Dr. Y S Parmar University of Horticulture and Forestry, Nauni, Solan (H.P.) India.

Kaushal NK, Joshi VK and Sharma RC (2002). Effect of stages of apple pomace collection and treatment on physio-chemical and sensory qualities of pomace leather. J Food Sci Technol, 39 (4): 388-393.

Koubala BB, Mbome LI, Kansci G, Tchouanguep MF, Crepeau MJ, Thibault JF and Ralet MC (2008). Physico-chemical properties of pectins from ambarella peels (Spondias cytherea) obtained using different 
extraction conditions. Food Chem, 106:1202-1207.

Lane J H and Eynon L (1923). Determination of reducing sugars by Fehling's solution with methylene blue as an indicator. $J$ Soc Chemical Ind, 42: 32T.

Lim J, Yoo J, Ko S and Lee S (2012). Extraction and characterization of pectin from Yuza (Citrus junos) pomace: A comparison of conventionalchemical and combined physical enzymatic Extractions. Food Hydrocolloids, 29:160-165.

Min B, Bae IY, Lee HG, Yoo SH and Lee S (2010). Utilization of pectin-enriched materials from apple pomace as a fat replacer in a model food system. Bioresource Technol, 101:5414-5418.

Mohd NS, Ramli IN, Hani NM and Meon Z (2012). Extraction and characterization of pectin from dragon fruit (Hylocereus polyrhizus) using various extraction conditions. Sains Malaysiana, 41(1): $41-45$.

Panouille M, Thibault JF and Bonnin E (2006). Cellulase and protease preparations can extract pectins from various plants byproducts. $J$ Agricl Food Chem, 54: 8926-8935.

Ptichkina NM, Markina OA and Rumyantseva GN (2008). Pectin extraction from pumpkin with the aid of microbial enzymes. Food Hydrocolloid,
22:192-195.

Ramli N and Asmawati (2011). Effect of ammonium oxalate and acetic acid at several extraction time and $\mathrm{pH}$ on some physicochemical properties of pectin from cocoa husks (Theobroma cacao). African J Food Sci, 5(15): 790-798

Ranganna S (1997). Manual of analysis of fruit and vegetable products. McGraw Hill, New Delhi. p 31-65

Shkodina OG, Zeltser OA, Selivanov NY and Ignatov VV (1998). Enzymic extraction of pectin preparations from pumpkin. Food Hydrocolloid, 12:313-316.

Sloan AE. 2010. Top 10 functional food trends. Food Technology. 64: 22-41.

Yapo BM. 2009. Lemon juice improves the extractability and quality characteristics of pectin from yellow passion fruit byproduct as compared with commercial citric acid extractant. Bioresource Technology. 100:3147-3151

Yuliarti O, Matia-Menno L, Goh MJA and Brcnnan CS (2011). Effect of Celluclast $1.5 \mathrm{~L}$ on the physic-chemical characterization of gold kiwifruit pectin. Int J Molecular Sci, 12: 6407-6417.

Zykwinska A, Boiffard MH, Kontkanen H, Buchert J, Thibault JF and Bonnin E (2008). Extraction of green labeled pectins and pectic oligosaccharides from plant by products. J Agric Food Chem. 56:8926-8935.

\section{How to cite this article:}

Vinay Chandel, Devina Vaidya, Anil Gupta, Manisha Kaushal and Anil Kumar Verma. 2019. Effect of Enzyme Concentration on Quality of Apple Pomace Pectin. Int.J.Curr.Microbiol.App.Sci. 8(01): 2843-2849. doi: https://doi.org/10.20546/ijcmas.2019.801.298 